International Journal of Educational Review

Volume 3 Issue 2 (2021) Page 257-264

ISSN 2685-709X (Online) 2685-905X (Print)

\title{
Simple Design and Build Automatic Transfer Switch Generator Set On Airport Power Station with Failure Indicator Protection
}

\author{
Catra Indra Cahyadi ${ }^{1}$ Yanti Daryanti ${ }^{2}$ Ahmad Bahrawi ${ }^{3}$ \\ ${ }^{1,2}$ Politeknik Penerbangan Palembang, ${ }^{3}$ Politeknik Penerbangan Makassar \\ Corresponding Author E-mail: catraindracahyadi@gmail.com
}

Received 18 November 2021; Revised 18 December 2021; Accepted 26

December 2021

\begin{abstract}
Electricity needs at airports are in direct need of backup and additional supplies apart from the main PLN source, such as generator sets. It is necessary to design a simple Automatic Transfer Switch that is connected to the main source operating failure indicator to a backup energy source. Research developed in order to provide benefits to airport operational management companies so that they are safe against energy needs in the event of an energy disturbance. Panel ATS is an abbreviation of the word Automatic Transfer switch, this tool serves to move the connection between one voltage source and another electrical voltage source automatically. The research was conducted by making ATS design. To ensure the design is appropriate and functioning properly, the panel tool is tested to function properly and can operate as desired. In carrying out the test, there are 3 ways, namely manual system testing on generator sets, manual system testing on modules and automatic systems. Measurement data is carried out at the time of testing automatically as well as seeing the function of each component running well. The results of the design that have been made can be used as a backup energy source if the main energy source is disturbed or trouble shooting or in an emergency, even if the energy source can function when the airport is operating and does not interfere with airport operations. Manual testing and automatic
\end{abstract}


interchange switch can switch power sources to load with an average time of 4.09 seconds.

Keywords: ATS, Automatic, backup energy

\section{Introduction}

Electricity needs at airports really need backup and additional supplies other than the main PLN source, such as generator sets and others with adequate capacity or according to airport operational needs to be used if the supply from PLN is interrupted such as a blackout. Over and under current So that the Automatic Transfer Switch control panel is needed to detect and move the electricity supply when experiencing a disturbance that functions automatically. PLN disturbances such as unstable frequency, electric current and extreme temperatures in connectors or machines that can cause damage to electrical equipment to unwanted accidents can certainly disrupt airport operations. Therefore, parameter values such as voltage, current, frequency, temperature really need to be monitored so that they do not go beyond the desired limits. Based on these problems, this research will design an Automatic Transfer Switch that is able to provide information on the parameters of Current, Temperature, and Frequency and the transfer of electrical energy sources automatically from the main PLN source to a backup source such as a generator set. When one or more parameters are outside the required conditions, the Automatic Transfer Switch will maneuver by moving the supply position to the generator set backup supply. The design that was built was in the form of a simple ATS with small power as a prototype for an airport backup energy source. The need for airport electrical energy is very large, of course, a panel with a large power is needed, but this research is limited to a simple ATS panel as an example of the need and work system if it is installed at the airport. With the ATS system, airport operations can still take place without any energy loss. In contrast to previous studies, this study focused on interchange design using TAKADA which is stronger and safer for changes with some protection against trouble shooting interference on the ATS panel. It can be in the form of additional sensor protection or overload protection and others similar to the interchange switch security system protection on switching current sources. The current transfer on this switch is done with a relay that is ON by a source from PLN, if PLN dies then the starter on the machine is connected which causes the generator set to turn on and issue current. The indicator that appears is Failure or failure from the PLN source so that the 
generator set backs up the power source from the backup generator. Design and build a simple Automatic Transfer Switch that is connected to the main source operating failure indicator to a much needed backup energy source and in accordance with the needs of the load energy source at the airport.

\section{Research Methods}

Data collection was carried out by using observations and measurements as well as designing and testing equipment functions properly. Using measuring tools to see the results of the effectiveness of the equipment. The data obtained are analyzed to obtain conclusions that are very useful for the use of equipment at airport power stations.

The block diagram is determined so that you can see the parts that function according to the needs of how the last works and make it easier to find trouble shooting if there is a disturbance in the system that has been designed to build. Each block has its own role and function, such as a battery charger that functions so that the battery for the starter remains good even if the generator is turned off or OFF. So that when the engine is started the engine can still turn on as it should.

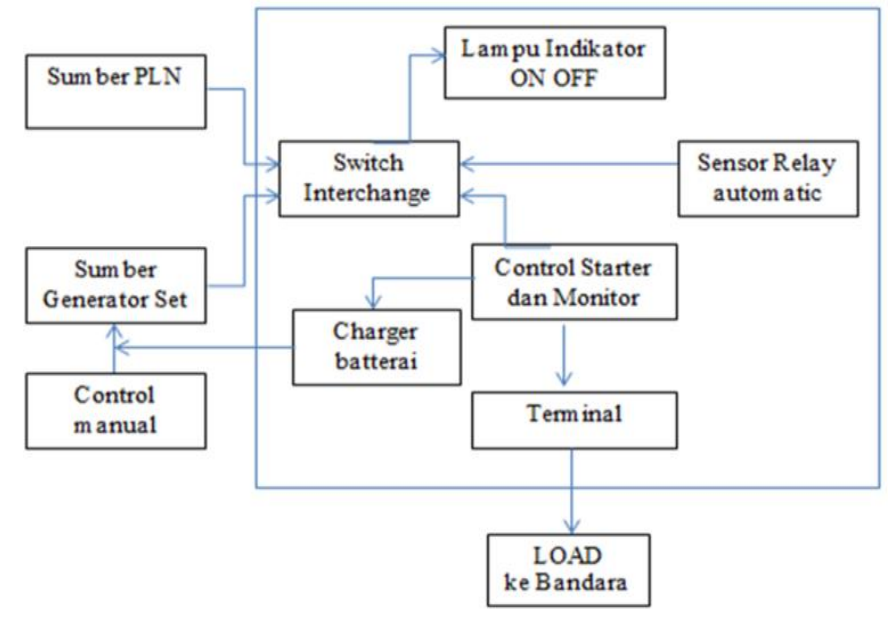

Figure 1. The ATS Diagram Block which is designed.

\section{Results and Discussion}

Paragraphs must be orderly. All paragraphs must be aligned, i.e. equally left and right aligned.

\section{A. PLN Current Source}

In the experiment and testing of the tool, a single phase power source was used. The main component of the source used is electric current from PLN which 
is used as a test of the function of the tool while still connecting the PLN power source to the equipment that has been designed as in the blog diagram listed in Figure 1.

\section{B. Backup energy source Generator Set The}

Backup energy used is a generator 5000 VA single phase at the time of the experiment because the equipment is designed for a simple prototype. If at the airport, determine to use a 3-phase energy source, but for experiments and research and data collection, small power and small capacity are used as a test for data collection and testing the function of the tool. The installed specification data are listed in the following table:

Table 1. Genset specifications used for Data Collectionsize Font for Articles

\begin{tabular}{rlcc}
\hline No & Specifications & \multicolumn{1}{c}{ Unit } & Value Quantity \\
\hline 1 & Rated power & $\mathrm{KVA}$ & $4.5 / 5$ \\
2 & Rated frequency & $\mathrm{Hz}$ & $50 / 60$ \\
3 & Rated Voltage & $\mathrm{V}$ & $230 /(240 / 120)$ \\
4 & Rated Current & $\mathrm{A}$ & $19.6 /(20.8 / 41.7)$ \\
5 & Power Factor & & 1.0 \\
6 & Rated Rotation Speed & r/min & $3000 / 3600$ \\
7 & Phase & & Single Phase \\
\hline
\end{tabular}

\section{Use of Equipment}

In general, ATS panels work by replacing the main energy source with backup energy in this case using a source PLN and Genset sources. ATS will move the connected source with the load alternately on the backup source by means of an Interchange switch. Either automatically or manually, so the same as $\mathrm{NO}$ and NC. If the main energy is normal then it will be connected to the load and the backup energy will be cut off. On the other hand, if the main energy is interrupted or extinguished, the interchange switch will connect the backup energy to the load. In general, it can be seen in Figure 4.15 block diagram of how the ATS automated system works. 


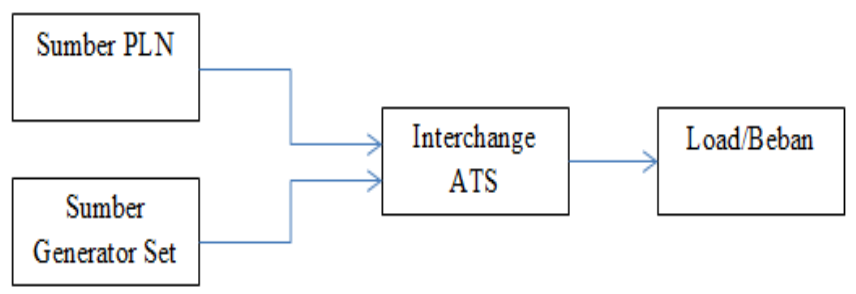

Figure 2 Block Diagram of How the ATS Works

\section{Testing of the Tool}

To ensure the design is appropriate and functioning properly, it is necessary to test the tool to see if the panel is functioning properly and can operate as desired. In carrying out the test, there are 3 ways, namely manual system testing on generator sets, manual system testing on modules and automatic systems which are very much needed in the operation of this tool. The method of testing the tool is carried out in the following way:

1) Testing with Manual Control Manual

2) testing with the Module is

3) Automatic Testing

ATS designed to turn off and turn on the power source in an automatic state in order to make it easier for technicians to carry out maintenance. And if there is a blackout at PLN then the source of electrical energy can be directly turned on and supplied with a very fast time. So technicians no longer need to run to the power station room which has been consuming time.

Automatic function is needed especially during the operating hours of the airport should not be interrupted source of electricity or sources other reserves because it could be detrimental if operation is disrupted and can be impaired safety systems on penerban at airports

\section{Results of Testing}

Data from pengetasan done is to check all the conditions of the components assembled in good condition and functioning as expected. The results of checking and testing can also be used to perform routine maintenance on the system. The components of checking and testing carried out are as follows:

Table II. Genset Specifications Used On Fontation Datacurrent for Article No 


\begin{tabular}{|c|c|c|c|c|}
\hline No & Part Checking & Condition & Value & Unit \\
\hline 1 & $\begin{array}{l}\text { Fuel Tank and Fuel } \\
\text { filter }\end{array}$ & Sufficiently & $\begin{array}{l}\text { Not up to the } \\
\text { minimum limit }\end{array}$ & liter \\
\hline 2 & $\begin{array}{l}\text { Engine Oil and oil } \\
\text { filter }\end{array}$ & $\begin{array}{l}\text { Sufficient and } \\
\text { appropriate }\end{array}$ & 3.5 & Bar \\
\hline 3 & Battery or Battery & $\begin{array}{l}\text { Charged } \\
\text { Voltage } \\
\text { and Current }\end{array}$ & $\begin{array}{l}12.8 \text { When } \\
\text { charging with } \\
\text { PLN and } 13.5 \\
\text { with Generator } \\
\text { alternator. } \\
\text { Current } 35\end{array}$ & $\begin{array}{l}\text { Ampere- } \\
\text { hour }\end{array}$ \\
\hline 4 & Starter & On when started & 12 & Volt \\
\hline 5 & Control Panel & $\begin{array}{l}\text { On during manual } \\
\text { test. } \\
\text { And can supply to } \\
\text { loads }\end{array}$ & & \\
\hline 6 & $\begin{array}{l}\text { Manual Control } \\
\text { Modules }\end{array}$ & $\begin{array}{l}\text { Function when } \\
\text { testing }\end{array}$ & & \\
\hline 7 & $\begin{array}{l}\text { Automatic system } \\
\text { testing }\end{array}$ & Functions & & \\
\hline 8 & Interchange switches & Can switch & & \\
\hline 9 & $\begin{array}{l}\text { PLN voltage sources } \\
1 \text { phase }\end{array}$ & Life & 220 & Volt AC \\
\hline 10 & $\begin{array}{l}\text { Generator voltage } \\
\text { source } 1 \text { phase }\end{array}$ & Live & 220 & Volt AC \\
\hline 11 & Load & 100 percent & 19 & Ampere \\
\hline 12 & lights Indicator & On & & \\
\hline 13 & Monitor screen is & On & & \\
\hline 14 & $\begin{array}{l}\text { The buttons on the } \\
\text { module are }\end{array}$ & working & & \\
\hline 15 & Battery charger is & working & & \\
\hline 16 & $\begin{array}{l}\text { Emergency buttons } \\
\text { are }\end{array}$ & $\begin{array}{l}\text { functioning } \\
\text { properly }\end{array}$ & & \\
\hline 17 & Relays are & $\begin{array}{l}\text { functioning } \\
\text { properly }\end{array}$ & & \\
\hline
\end{tabular}


Measurement data on voltage are as follows:

Table III. Genset Specifications Used On Footing Datakull Font for Articles

\begin{tabular}{llccc}
\hline No & \multicolumn{1}{c}{ Measurement } & $\begin{array}{c}\text { Monitor Screen } \\
\text { Display Module }\end{array}$ & $\begin{array}{c}\text { Values on } \\
\text { Measurement Tool }\end{array}$ & Unit \\
\hline 1 & PLN & 220 & 220 & Volt AC \\
2 & $\begin{array}{l}\text { Source Generator } \\
\text { Voltage Source }\end{array}$ & 230 & 230 & Volt AC \\
3 & $\begin{array}{l}\text { Battery when PLN } \\
\text { ON }\end{array}$ & 12.8 & 12.7 & Volt DC \\
4 & $\begin{array}{l}\text { Battery when Genset } \\
\text { is ON }\end{array}$ & 13.5 & 13.5 & Volt DC \\
5 & $\begin{array}{l}\text { Load almost 100 } \\
\text { percent }\end{array}$ & 19 & 18.9 & Ampere \\
\hline
\end{tabular}

\section{Conclusion}

From the results of design, testing and field measurements, conclusions can be drawn from this research:

1. The results of the design that have been made can be used as a backup energy source if the main energy source is interrupted or trouble shooting or in an emergency, even if the energy source can function when the airport is operating and does not interfere with airport operations. This prototype can be applied to airport power stations.

2. After manual and automatic testing, the interchange switch can switch power sources to load with an average time of 4.09 seconds

3. In addition to the automatic system in the design, a manual system must still be made so that the system can run if there is an automatic disturbance.

\section{References}

Cooper, WD, 1985, Electronics Instrumentation and Measurement Techniques, Prentice Hall. Ditya Herin Damara, mohammad Ramdhani, ilhamsyah. 2015.

Eko Susanto, 2013. Automatic Transfer Switch. Journal of Electrical Engineering Vol.5 No.1

Ginting Paul Hendry, Enda Wista Sinuraya. 2014. Design of Automatic Transfer

Switch (Ats) Transition Mode Open-Transition Re-Transfer With Transition 
Parameters In The Form Of Voltage And Frequency. Transmission. 16. 03:130.

Halliday, David. 2003. "Fundamentals of Physics". United States of America: John Wiley and Sons. Inc.

Mahun LLJ, 1992, Diesel Generator Handbook, Elsevier Butterworth-heinemann.

Mansen July, Novery Lysbetti. 2016. Design of Prototype Automatic

Transfer Switch (Ats) for Category 2e Loads at Inpatient Health Centers Based on Atmega16 Microcontroller. 03. 02:1-8.

MLX90614.November.2017 www.sparkfun.com

Perdana Wandi. 2015. Power Switching In Automatic Transfer Switch In Maintaining The Reliability Of Power Supply That Is Powered From Pln And Generators. Hope Together Polytechnic. Journal of Electrical Engineering.

Product Design of Automatic Switch Breaker With Multi-Clock Clock Based on Microcontroller Automatic Switch Breaker Product Design With Stopwatch Based On Microcontroller. e-Proceedings of Applied Science. 01. 03:24425826.

Riny Sulistyowati, Dedi Dwi Febriantoro. 2012. Prototype Design of Microcontroller-Based Control and Monitoring System for Electrical Power Limiters. Industrial Technology Faculty. 16. 01:Science and Technology Journal

Setiawan Arif. 2015. Design and Build of Microcontroller-Based Automatic Timer Switch Breaker Products. 01. 3: 2565-25 Poudel, P., Hansen, C., Sprung, J., \& Friebe, M. (2016). 3D segmentation of thyroid ultrasound images using active contours. Current Directions in Biomedical Engineering, 2(1), 467-470. https://doi.org/10.1515/cdbme-2016-0103

Szabo, TL (2014). Diagnostic Ultrasound Imaging: Inside Out. Diagnostic Ultrasound Imaging: Inside Out: Second Edition. Elsevier. https://doi.org/10.1016/C2011-0-07261-7

Wunderling, T., Golla, B., Poudel, P., Arens, C., Friebe, M., \& Hansen, C. (2017) . Comparison of thyroid segmentation techniques for 3D ultrasound. In MA Styner \& ED Angelini (Eds.) (p. 1013317). https://doi.org/10.1117/12.2254234 